\title{
Hot-Filament Metal Oxide Deposition (HFMOD): A Novel Method for Depositing Thin Films of Metallic Oxides
}

\author{
F. Paulo Rouxinol, B. Cláudio Trasferetti, Richard Landers and Mário A. Bica de Moraes* \\ Instituto de Física "Gleb Wataghin", Universidade Estadual de Campinas, CP 6165, \\ 13.087-970 Campinas - SP, Brazil
}

\begin{abstract}
O presente artigo descreve um novo método para a síntese de filmes finos de óxidos metálicos. Um filamento de metal, que pode ser aquecido por uma fonte de corrente alternada é instalado numa câmara de vácuo. Por meio de um fluxômetro de massa, oxigênio pode ser admitido no interior da câmara. Da reação entre o oxigênio e o metal do filamento aquecido, espécies de óxidos voláteis $\mathrm{Me}_{\mathrm{x}} \mathrm{O}_{\mathrm{y}}$, onde $\mathrm{Me}$ é o metal, são formadas, se condensando num substrato colocado próximo ao filamento, formando o filme. Foi observado que os filmes finos de $\mathrm{W}_{\mathrm{x}} \mathrm{O}_{\mathrm{y}}$ e $\mathrm{Mo}_{\mathrm{x}} \mathrm{O}_{\mathrm{y}}$ podem ser depositados de forma satisfatória por este novo método. Embora várias outras técnicas de análise tenham sido usadas para caracterizar os óxidos, esta nota enfatiza os resultados obtidos por espectroscopia de fotoelétrons de raio-X (XPS).
\end{abstract}

This short report describes a novel method for the synthesis of metal oxide thin films. The experimental setup consists of a metal filament installed inside a vacuum chamber. The filament can be heated by an ac power supply while oxygen is admitted into the chamber using a mass flowmeter. From reactions between oxygen and the heated metal filament, volatile oxide species, $\mathrm{Me}_{\mathrm{x}} \mathrm{O}_{\mathrm{y}}$, where Me is the metal, can be formed, condensing on a nearby substrate. We have observed that thin films of $\mathrm{W}_{\mathrm{x}} \mathrm{O}_{\mathrm{y}}$ and $\mathrm{Mo}_{\mathrm{x}} \mathrm{O}_{\mathrm{y}}$ can be satisfactorily deposited by this novel method. Although several techniques were used to characterize the oxides, this note emphasizes the results obtained by X-ray Photoelectron Spectroscopy (XPS).

Keywords: $\mathrm{WO}_{3}, \mathrm{MoO}_{3}$, thin films, XPS, CVD

\section{Introduction}

Metallic oxides are important materials from the standpoint of both fundamental and applied science. Particularly, tungsten and molybdenum oxide films have been the focus of extensive scientific investigations due to their prospective technological applications in $(i)$ electrochromic devices, ${ }^{1,2}$ (ii) gasochromic sensors, ${ }^{3,4}$ and (iii) electrocatalysis. ${ }^{5,6}$ However, their most intensively investigated property so far is the electrochromism. $\mathrm{WO}_{3}$ films are considered one of the most viable options in emerging electrochromic technology, ${ }^{1}$ being applicable for regulating the throughput of radiant energy in smart windows and antidazzling mirrors. These oxides have also been used as "templates" in the synthesis of composites of the type transition metal oxide/conducting polymer, generating promising results in the area of cathodic materials in secondary lithium batteries. ${ }^{7}$

* e-mail: bmoraes@ifi.unicamp.br
Several deposition techniques such as sputtering, ${ }^{8-10}$ thermal evaporation, ${ }^{3,11}$ plasma-enhanced chemical vapor deposition $^{12}$ and sol-gel ${ }^{13,14}$ have been used to obtain tungsten and molybdenum oxide films. This report describes the development of a new deposition method, which we have called hot filament metal oxide deposition (HFMOD), using a metallic filament heated in a rarefied oxygen atmosphere. The film is formed on a substrate positioned near the filament and the deposition rate is controlled by the filament temperature and the oxygen pressure. Both the thermochemistry of the process and the kinetics of film formation are currently under investigation. It is clear, however, that the film is formed from volatile $\mathrm{Me}_{\mathrm{x}} \mathrm{O}_{\mathrm{y}}$ precursors, where $\mathrm{Me}$ is the metal, generated on the heated tungsten surface from reactions between oxygen and tungsten. The investigations so far carried out in our laboratory show that the films can be deposited with a good stoichiometry control, with relatively high deposition rates and present good adhesion to both metallic and dielectric substrates. Tests on the electrochromical 
properties carried out on samples of $\mathrm{WO}_{3}$ show that their optical efficiency is higher than those of $\mathrm{WO}_{3}$ films obtained by the above-mentioned techniques. It is also important to remark that this technique differs from a deposition technique called hot filament chemical vapor deposition (HFCVD), which have been used to deposit siloxane ${ }^{15}$ and diamond-like films, ${ }^{16}$ because the filament used here is not just a "catalyst" used to activate chemical species; it is also a reactant in the reaction.

\section{Experimental}

Figure 1 depicts the experimental deposition setup that was designed in our laboratory for the deposition of transition metal oxides. The filament $(\mathrm{F})$, which is made of the metal of the oxide to be deposited, is resistively heated by an ac current supply. Oxygen is admitted to the chamber via an electronic mass flowmeter. Pressure measurements are made using a capacitance manometer. During the depositions the chamber is continuously pumped by a Roots pump and the oxygen pressure is adjusted using the flowmeter. The chamber base pressure is about $2.0 \times 10^{-2} \mathrm{~Pa}$. Substrate temperatures are measured using a chromel-alumel thermocouple and filament temperatures are determined with an optical pyrometer through a glass viewpoint in the wall of the deposition chamber.

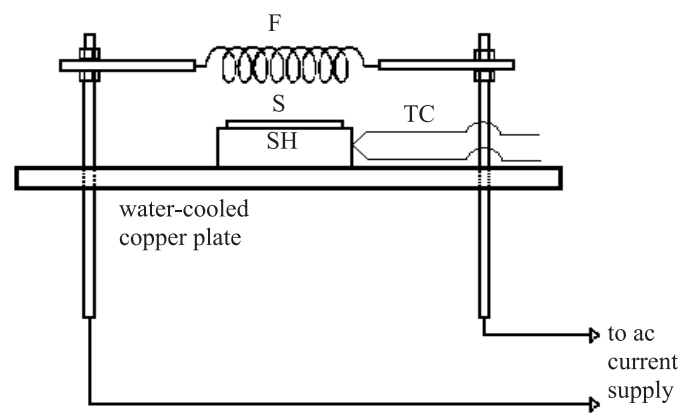

Figure 1. Schematic representation of the experimental arrangement inside the chamber. F- filament of $0.4 \mathrm{~mm}$ (tungsten) and 0.6 $\mathrm{mm}$ (molybdenum) diameter metal wire, shaped into a seven-turn coil of $8 \mathrm{~mm}$ diameter and $35 \mathrm{~mm}$ length; $\mathrm{S}$ - substrate; $\mathrm{SH}$ - copper substrate holder of $50 \times 30 \times 7 \mathrm{~mm}^{3}$; TC - thermocouple; filamentto-substrate separation: $30 \mathrm{~mm}$.

In order to characterize the structure of the deposited films, several techniques were used such as Infrared Reflection-Absorption Spectroscopy (IRRAS), Rutherford Backscattering (RBS), X-ray Photoelectron Spectroscopy (XPS), UV-vis Absorption Spectroscopy, Single Wavelength Ellipsometry (SWE) and Raman Spectroscopy. The electrochromic properties of the films were also investigated by means of spectroelectrochemical measurements in the visible range. Manuscripts describing all these results are currently being prepared and will be submitted to scientific journals.

For the purposes of this report, only XPS results will be presented and discussed. For the XPS analyses, a hemispherical spectrometer using the unmonochromatized $\mathrm{K} \alpha \mathrm{X}$-ray line of aluminum was employed. To investigate the possible tungsten or molybdenum valence states, the 4f-doublet peak or the 3d-doublet peak, respectively, were fitted with Gaussian peaks corresponding to known bonding states of tungsten and oxygen.

\section{Results and Discussion}

The XPS data were gathered for a $\mathrm{W}_{\mathrm{x}} \mathrm{O}_{\mathrm{y}}$ and $\mathrm{a} \mathrm{Mo}_{\mathrm{x}} \mathrm{O}_{\mathrm{y}}$ sample deposited with the conditions given in Table 1.

The tungsten 4f XPS spectrum (squares) for sample WO is shown in Figure 2. As can be seen from that figure, the $4 \mathrm{f}$ profile can be fit by two Gaussian peaks centered at 37.7 and $35.5 \mathrm{eV}$ which are, respectively, the binding energy of electrons in the $4 f_{5 / 2}$ and $4 f_{7 / 2}$ levels of tungsten in the $\mathrm{W}^{+6}$ valence state, ${ }^{17}$ indicating that the film is composed of stoichiometric $\mathrm{WO}_{3}$.

Table 1. Deposition parameters of the $\mathrm{W}_{x} \mathrm{O}_{y}$ and $\mathrm{Mo}_{x} \mathrm{O}_{\mathrm{y}}$ films presented in this work

\begin{tabular}{cccc}
\hline Sample & Filament & $\begin{array}{c}\text { Temperature } \\
\left({ }^{\circ} \mathrm{C}\right)\end{array}$ & $\begin{array}{c}\text { Oxygen } \\
\text { Pressure }(\mathrm{Pa})\end{array}$ \\
\hline $\mathrm{WO}$ & $\mathrm{W}$ & 1320 & 0.8 \\
$\mathrm{MoO}$ & $\mathrm{Mo}$ & 1550 & 1.7 \\
\hline
\end{tabular}

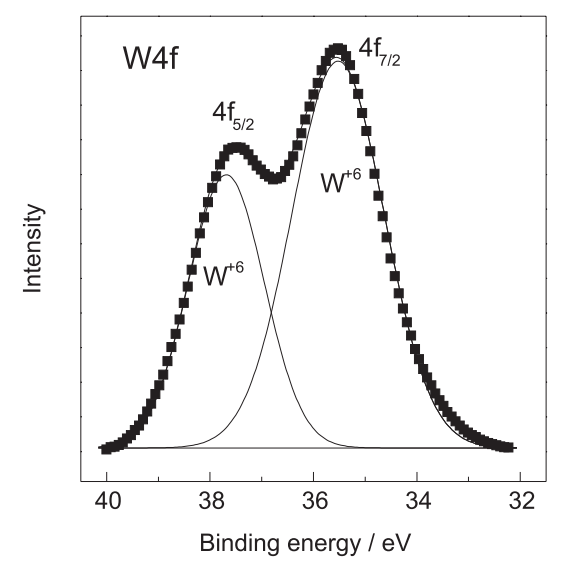

Figure 2. XPS spectrum of the W4f core levels for sample WO (Filament temperature of $1320{ }^{\circ} \mathrm{C}$ and oxygen pressure of $0.8 \mathrm{~Pa}$ ). The thicker line is the fitting of the experimental data (squares) by the Gaussian peaks (thin lines).

Figure 3 presents the XPS spectrum of the Mo3d core levels for sample MoO. As can be seen from that figure, the $3 \mathrm{~d}$ profile can be fit by two pairs of Gaussian peaks. The most intense pair is centered at 235.8 and $232.7 \mathrm{eV}$ which 
are, respectively, the binding energy of electrons in the $3 \mathrm{~d}_{3 / 2}$ and $3 \mathrm{~d}_{5 / 2}$ levels of molybdenum in the $\mathrm{Mo}^{+6}$ valence state. The other pair is centered at 234.6 and $231.6 \mathrm{eV}$ corresponding to the binding energy of electrons in the same $3 \mathrm{~d}$ levels, but in $\mathrm{MoO}^{+5}$ valence state. For both valence states, these binding energies are in close agreement with literature values. ${ }^{18,19}$ Therefore, it was concluded that the Mo atoms were in mixed valence states, $\mathrm{Mo}^{+6}$ and $\mathrm{Mo}^{+5}$, with a high predominance of the former over the latter. Thus the film was in the overall $\mathrm{MoO}_{\mathrm{x}}$ stoichiometry, with $\mathrm{x}$ smaller but close to 3 . The observation that the film stoichiometry is close to that of $\mathrm{MoO}_{3}$, is consistent with the expectation that the film is formed from $\mathrm{MoO}_{3}$ and $\mathrm{MoO}_{2}$ species desorbed from the Mo filament and that the desorption rate of the former is greater than that of the latter.

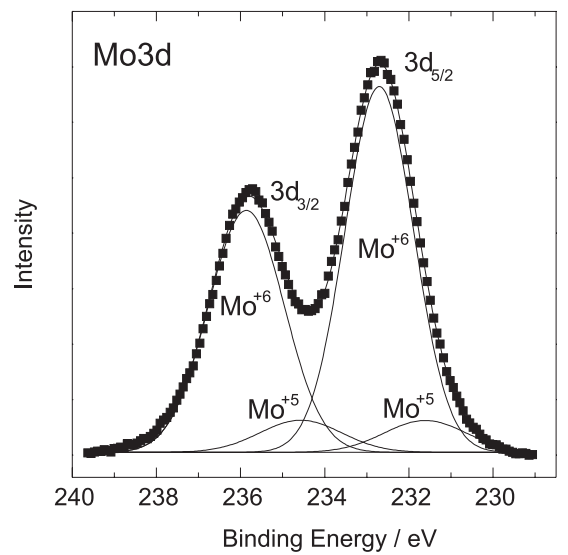

Figure 3. XPS spectrum of the Mo3d core levels for sample MoO (Filament temperature of $1550{ }^{\circ} \mathrm{C}$ and oxygen pressure of $1.7 \mathrm{~Pa}$ ). The thicker line is the fitting of the experimental data (squares) by the Gaussian peaks (thin lines).

The spectra of Figures 2 and 3 are representative of other spectra of samples prepared with oxygen flow rates in the interval between 6.0 and $21 \mathrm{sccm}$ and the same filament temperatures. Thus the chemical composition of the films does not significantly change in this oxygen flow rate range.

\section{Conclusions}

By means of the unexpensive and simple deposition technique described in this note, it was possible to deposit $\mathrm{W}_{\mathrm{x}} \mathrm{O}_{\mathrm{y}}$ and $\mathrm{Mo}_{\mathrm{x}} \mathrm{O}_{\mathrm{y}}$ films with $\mathrm{x}$ close to 3 . Several details about the role played by the deposition parameters on the overall structure and properties of the films are underway in our laboratory.

\section{Acknowledgements}

The authors thank the Fundação de Amparo à Pesquisa do Estado de S. Paulo-FAPESP (grants number 02/07482-6 and 98/10979-2), the Conselho Nacional de Desenvol- vimento Científico e Tecnológico (CNPq), and Coordenação de Aperfeiçoamento de Pessoal de Nível Superior for financial support. Thanks are also due to R. C. G. Vinhas who provided excellent technical assistance with XPS analysis.

\section{References}

1. Granqvist, C. G. In The CRC Handbook of Solid State Electrochemistry, Gellings, P. J.; Bouwmesster, H. J. M. eds.; CRC Press, Inc.: Cleveland Ohio, 1997, ch. 16.

2. Bange, K.; Sol. Energy Mater. Sol. Cells 1999, 58, 1.

3. Lee, S. -H.; Cheong, H. M.; Liu, P.; Smith, D.; Tracy, C. E.; Mascarenhas, A.; Pitts, J. R.; Deb, S. K.; J. Appl. Phys. 2000, 88, 3076.

4. Solis, J. L.; Saukko, S.; Kish, L.; Granqvist, C. G.; Lantto, V.; Thin Solid Films 2001, 391, 255.

5. Roland, J. F.; Anson, F. C. ; J. Electroanal. Chem. 1992, 336, 245.

6. Habazaki, H.; Hayashi, Y.; Konno, H.; Electrochim. Acta 2002 , 47, 4181.

7. Varela, H.; Huguenin, F.; Malta, M.; Torresi, R. M.; Quim. Nova 2002, 25, 287.

8. Witham, H. S.; Chindaudom, P.; An, I.; Collins, R. W.; Messier, R.; Vedam, K.; J. Vac. Sci. Technol. A 1993, 11, 1881.

9. Taylor, T. A.; Patterson, H. H.; Appl. Spectrosc. 1994, 48, 674.

10. Cazzanelli, E.; Papalino, L.; Pennisi, A.; Simone, F.; Electrochim. Acta 2001, 46, 1937.

11. Bohnke, O.; Frand, G.; Fromm, M.; Weber, J.; Greim, O. ; Appl. Surf. Sci. 1996, 93, 45.

12. Henley, W. B.; Sachs, G. J.; J. Electrochem. Soc. 1997, 144, 1045 .

13. Santato, C.; Odziemkowski, M.; Ulmann, M.; Augustynski, J.; J. Am. Chem. Soc. 2001, 123, 10639.

14. Sharma, N.; Deepa, M.; Varshney, P.; Agnihotry, S. A.; Thin Solid Films 2001, 401, 45.

15. Pryce Lewis, H. G.; Casserly, T. B.; Gleason, K. K.; J. Electrochem. Soc. 2001, 148, F212.

16. Li, C.; Feng, K. C.; Yuan, H. T.; Xiong, Y.; Feng, K.; Appl. Surf. Sci. 2003, 207, 169.

17. Wagner, C. D.; Riggs, W. M.; Davis, L. E.; Moulder, J. F. In Handbook of X-ray Photoelectron Spectroscopy; Muilenberg, G. E.; ed., Perkin Elmer Corp.: Eden Praire, MN, 1979, p. 146, and references therein.

18. Fleisch, T. H.; Mains, G. J.; J. Chem. Phys. 1982, 76, 780.

19. Colton, R. J.; Guzman, A. M.; Rabalais, J. W.; J. Appl. Phys. 1978, 49, 409.

Received: July 29, 2003

Published on the web: February 13, 2004

FAPESP helped in meeting the publication costs of this article. 